Oliver, I. T. \& Peel, J. L. (1956). Biochim. biophys. Acta, 20, 390.

Ormerod, J. G. (1956). Biochem. J. 64, 373.

Peel, J. L. (1955). Abstr. 3rd Int. Congr. Biochem. Brussels, Section 10, 94.

Rose, I. A., Manago, M. G., Korey, S. R. \& Ochoa, S. (1954). J. biol. Chem. 211, 737.

Stadtman, E. R. (1953). J. biol. Chem. 203, 501.
Stadtman, E. R. \& Barker, H. A. (1950). J. biol. Chem. 184, 769.

Stadtman, E. R., Novelli, G. D. \& Lipmann, F. (1951). J. biol. Chem. 191, 365.

Walker, D. J. (1958a). Biochem. J. 69, 524.

Walker, D. J.(1958b). Ph.D.Thesis, University of Sheffield. Walker, D. J. \& Ladd, J. N. (1958). Biochem. J. 69, 29 P. Westerkamp, H. (1933). Biochem. Z. 263, 239.

\title{
Studies on Gastric Proteolysis
}

\section{THE NATURE OF THE ENZYME-SUBSTRATE INTERACTION RESPONSIBLE FOR GASTRIC PROTEOLYTIC pH-ACTIVITY CURVES WITH TWO MAXIMA*}

\author{
BY W. H. TAYLOR \\ Department of Clinical Biochemistry, Radcliffe Infirmary, University of Oxford
}

(Received 23 July 1958)

Human gastric juice and swine and calf gastricmucosal extracts have been shown to digest proteins other than egg albumin with two and occasionally three $\mathrm{pH}$ maxima below $\mathrm{pH} 5$, under experimental conditions which exclude the possibility that the maxima result from the presence of buffer anions or of more than one substrate component (Taylor, 1956, 1959).

The two maxima result therefore from the interaction of a gastric proteolytic enzyme or enzymes with the substrate. The nature of this interaction is now investigated further.

\section{THEORETICAL}

There are at least nine possible ways in which a pH-activity curve with two maxima could be produced.

(1) Two separate enzymes $\left(E_{1}\right.$ and $\left.E_{2}\right)$ may be present, each attacking the protein substrate at different optimum $\mathrm{pH}$ values:

$$
\begin{aligned}
& E_{1}+S \rightarrow E_{1} S \\
& E_{2}+S \rightarrow E_{2} S
\end{aligned}
$$

This explanation has been adopted, initially at least, by others who find that two $\mathrm{pH}$ maxima genuinely occur (e.g. Freudenberg, 1940; Buchs, 1947; Merten \& Ratzer, 1949). The two enzymes are considered to be pepsin and a cathepsin.

(2) A single enzyme may be present which possesses two types of active centre, each attacking the same site or sites of the substrate optimally at different $\mathrm{pH}$ values.

$$
\begin{gathered}
2 \mathrm{E}_{a+b}+2 \mathrm{~S} \rightarrow \mathrm{E}_{a} \mathrm{~S}+\mathrm{E}_{b} \mathrm{~S} \\
\text { * Part 1: Taylor (1959). }
\end{gathered}
$$

(3) A single enzyme with two types of active centre may attack, with each, a different type of substrate site.

$$
2 \mathrm{E}_{a+b}+2 \mathrm{~S}_{x+y} \rightarrow \mathrm{E}_{a} \mathrm{~S}_{x}+\mathrm{E}_{b} \mathrm{~S}_{y}
$$

(4) A single enzyme with only one type of active centre may attack the substrate molecule at two different types of site.

$$
2 \mathrm{E}+2 \mathrm{~S}_{x+y} \rightarrow \mathrm{ES}_{x}+\mathrm{ES}_{y}
$$

These four hypotheses have in common the idea that pH-activity curves with double maxima result from enzyme-substrate interaction at two different sites.

The remaining hypotheses postulate that two maxima may result from enzyme-substrate interaction at a single type of site.

(5) A single enzyme with only one type of active centre may attack the substrate molecule at only one site but, because of the presence of an inhibitor with optimum activity at a pH between 2.5 and 3.2 , a digestion optimum in this region might be converted into a minimum with maxima on either side.

(6) No attempt has yet been made to extend the theories which account for the origin of single $\mathrm{pH}$ maxima to the special case of double maxima. The classical explanation of the effect of $\mathrm{pH}$ upon enzyme activity is that of Michaelis (1914), who found that $\mathrm{pH}$-activity curves could be accurately calculated on the assumption that the enzyme was a weak acid or base and that the activity was due either to the ion or the undissociated molecule, depending on the nature of the enzyme. In terms of the more modern zwitterionic theory one may postulate, for example, an active part of the enzyme consisting of basic and acidic groups 
$\mathrm{NH}_{3}+\ldots \mathrm{CO}_{2}{ }^{-}$. When acid is added, inactive $\mathrm{NH}_{3}+\ldots \mathrm{CO}_{2} \mathrm{H}$ is formed; with alkali, inactive $\mathrm{NH}_{2} \ldots \mathrm{CO}_{2}-$. In such a case the typical bellshaped symmetrical $\mathrm{pH}$-activity curve so often seen would be predicted. If either of the lastnamed two forms happened to be the active one, a bell-shaped curve would similarly be obtained, one limb being due to the formation of inactive zwitterion and the other to denaturation of the active form at the extremes of $\mathrm{pH}$. In order to explain a double maximum in terms of ionic effects it is necessary to postulate that at least two ionic forms of the enzyme are active, e.g. $\mathrm{NH}_{2} \cdot \mathrm{CO}_{2}{ }^{-}$ and $\mathrm{NH}_{3}+\ldots \mathrm{CO}_{2} \mathrm{H}$, with the intermediate zwitterion, $\mathrm{NH}_{3}+\ldots \mathrm{CO}_{2}^{-}$, inactive.

(7) It has been observed (Northrop, 1922; Kunitz \& Northrop, 1934) that the $\mathrm{pH}$ optimum of endopeptidases such as pepsin varies with different protein substrates, and the classical theory of Michaelis has been extended to account for this by postulating that the active ionic form of the enzyme can combine with only one ionic form of protein substrate. For pepsin, evidence from titration curves (Northrop, Kunitz \& Herriott, 1948 ) indicates that it is the positive protein substrate ion that is involved. The occurrence of a double pH maximum might therefore be postulated if, for example, both positive and negative substrate ions could form active enzyme-substrate complexes but not the intermediate protein zwitterion

$$
\begin{aligned}
& \mathrm{E}+\mathrm{S}^{+} \rightarrow \mathrm{ES}^{+} \\
& \mathrm{E}+\mathrm{S}^{-} \rightarrow \mathrm{ES}^{-}
\end{aligned}
$$

(8) Gutfreund (1955) and Hammond \& Gutfreund (1955) have shown that when trypsin and chymotrypsin act upon synthetic substrates with a single hydrolysable bond, the reaction of the enzyme with its substrate involves two separate steps, first an initial fast adsorption at the specificity site and secondly a slow, rate-determining step involving a reaction at the catalytic site, which are independent of each other. It has been found that the Michaelis constant, $K_{m}$, is the true dissociation constant of the initial step and varies with $\mathrm{pH}$. Similarly, the rate constant for the second step is also dependent on $\mathrm{pH}$. The resulting $\mathrm{pH}$ maximum is the resultant of these two separate effects. In these examples with trypsin and chymotrypsin, the two effects are simple and combine to give a typical single $\mathrm{pH}$ maximum. Clearly, however, if the variation of one or both of these factors were complex, as when papain hydrolyses $\alpha$-benzoyl-L-argininamide (Smith, Finkel \& Stockell, 1955), and the $K_{m}$ at $38.3^{\circ}$ undergoes two minima and a maximum between pH 4 and 9, or if the simple pH effects on each step were optimum at widely differing $\mathrm{pH}$ values, a double $\mathrm{pH}$ maximum might arise.
(9) Lastly, it is probable that the action of pepsin upon proteins is a complex one. After an initial splitting of the molecule at one or more points, it may be that the products are themselves further attacked by the enzyme. If the latter reaction has a different $\mathrm{pH}$ maximum from that of the initial reaction the overall process might show two maxima at different $\mathrm{pH}$ values.

$$
\begin{array}{ll}
\text { At one } \mathrm{pH} & \mathrm{E}+\mathrm{S} \rightarrow \mathrm{ES} \rightarrow \mathrm{E}+\mathrm{P} \\
\text { At another } & \mathrm{E}+\mathrm{P} \rightarrow \mathrm{EP} \rightarrow \mathrm{E}+\mathrm{Q}+\mathrm{R}, \text { etc. }
\end{array}
$$

Experiments designed to distinguish between these various hypotheses are now described.

\section{EXPERIMENTAL AND RESULTS}

The materials and methods used have been described previously (Taylor, 1957, 1959).

\section{Attempts to separate peptic and 'catheptic' activities}

Fractionation with salt solutions. Repeated fractionation of normal human gastric juice and swine mucosal extracts with ammonium sulphate, sodium chloride and magnesium sulphate and with combinations of all three have failed to achieve separation of the two maxima. Treatment with these salt solutions sometimes caused the ratio of proteolytic activity at the two maxima to vary (Table 1), and such alterations were examined carefully lest partial separation were occurring. However, a rise in peptic or 'catheptic' activity relative to the other in a precipitate or supernatant was not usually counterbalanced by a relative rise of activity at the other maximum in the corresponding supernatant or precipitate. It is concluded therefore that variations of the peptic/ 'catheptic' ratio could not be interpreted as removal or partial separation of either component, but rather as the destruction or inactivation of the activity at one or other maximum.

Adsorption studies. Attempts were made to adsorb material responsible for one or other $\mathrm{pH}$ maximum on calcium phosphate gel and ionexchange resins. The former is perhaps not ideal for the purpose, because formation of the gel is only possible at $\mathrm{pH}$ values which also slowly inactivate both postulated enzymes. However, by carrying out the adsorption at as low a temperature, as low a $\mathrm{pH}$ and for as short a time as possible, it was found that activity could be obtained both in the supernatant material and in the eluate from the adsorption complex (Table 1). In all experiments, however, it was found that the eluate, the supernatant and the original juice had very similar pHactivity curves, each with two maxima. No separation of peptic and 'catheptic' activities was therefore achieved by this technique. 
Wilkinson \& Martin (1946) were able to demonstrate the action of pepsin upon egg albumin after its adsorption upon Amberlite IR-4. It is known that pepsin is an anion, at least as low as $\mathrm{pH} 1$ (Ringer, 1915; Northrop, 1925; Tiselius, Henschen \& Svensson, 1938), and it might therefore be expected that separation from 'cathepsin' could be achieved at low pH with a suitable resin. Gastric juice was therefore shaken intermittently for $3 \mathrm{hr}$. with the activated resins Amberlite IR-4 and De-Acidite FF. The resins were then removed by centrifuging and eluted. In each case activity was present in both supernatant and eluate (Table 1), but no separation of peptic and 'catheptic' activities was obtained, nor were the ratios of activity at the optima altered in such a way as to suggest even a partial separation of one or other activity (Fig. 1). Lack of separation would suggest one of two possibilities: either 'cathepsin' is also an anion at low pH or 'peptic' and 'catheptic' activities are part of the same molecule.

Electrophoresis in the Tiselius apparatus. Normal gastric juice and mucosal extracts contain proteins other than enzymes, particularly mucoproteins, which can only be removed with difficulty. The techniques which have been used for this purpose (see Northrop et al. 1948) sometimes alter the properties of the enzymes that are present. Acetone precipitation of mucoprotein, for example (Norris \& Elam, 1940), inactivates or destroys the 'catheptic' activity, yielding pepsin crystals with only one $\mathrm{pH}$ maximum, around $2 \cdot 0$, instead of two, so that purification in this way results in the elimination of the very activity which it is hoped to separate. A simpler means of freeing gastric juice of its mucoproteins was therefore devised, before the juice could be analysed electrophoretically.

The bulk of the mucoprotein of gastric juice can be precipitated in the cold around pH 2.5. Such a precipitation was combined with the concentration

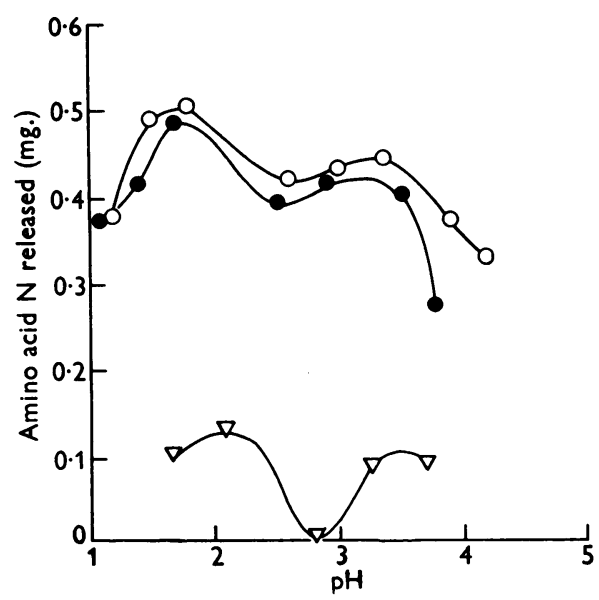

Fig. 1. Adsorption upon Amberlite IR-4 of the proteolytic activity of normal human gastric juice. pH-activity curves: $O$, of original juice; $O$, of the supernatant after removing the resin; $\nabla$, of the eluate from the resin. Plasma protein as substrate; temp., $37^{\circ}$; time, $3 \mathrm{hr}$.

Table 1. Effect of fractionation and adsorption procedures upon the proteolytic activity of human gastric juice and swine mucosal extracts at the two maxima

In this table and in the figures, the amounts of liberated amino acid nitrogen are those in the whole digest, consisting of $3 \mathrm{ml}$. of buffer, $1 \mathrm{ml}$. of enzyme extract or gastric juice, and $1 \mathrm{ml}$. of plasma or of $5 \%(w / v)$ albumin.

\begin{tabular}{|c|c|c|c|c|c|c|}
\hline Enzyme & Substrate & $\underset{\text { maximum }}{\mathrm{pH}}$ & $\begin{array}{l}\text { Amino } \\
\text { acid } N \\
\text { liberated } \\
\text { (mg.) }\end{array}$ & $\underset{\text { maximum }}{\mathrm{pH}}$ & $\begin{array}{l}\text { Amino } \\
\text { acid N } \\
\text { liberated } \\
\text { (mg.) }\end{array}$ & $\begin{array}{l}\text { Peptic/ } \\
\text { 'catheptic' } \\
\text { ratio }\end{array}$ \\
\hline $\begin{array}{l}\text { extract } \\
\text { onium sulphate fraction } \\
\text { monium sulphate }\end{array}$ & Plasma protein & $\begin{array}{l}2 \cdot 2 \\
2 \cdot 1 \\
2 \cdot 0\end{array}$ & $\begin{array}{l}0 \cdot 63 \\
0 \cdot 23 \\
0 \cdot 58\end{array}$ & $\begin{array}{l}3 \cdot 3 \\
3 \cdot 3 \\
3 \cdot 3\end{array}$ & $\begin{array}{l}0 \cdot 61 \\
0 \cdot 17 \\
0 \cdot 58\end{array}$ & $\begin{array}{l}1.03 \\
1.35 \\
1 \cdot 00\end{array}$ \\
\hline ic juice & $\begin{array}{l}\text { Human serum } \\
\text { albumin }\end{array}$ & $2 \cdot 2$ & $0 \cdot 36$ & $\mathbf{3} \cdot \mathbf{3}$ & $0 \cdot 32$ & $1 \cdot 12$ \\
\hline $\begin{array}{l}\text { Cl fraction } \\
\text { from } 100 \% \mathrm{NaCl}\end{array}$ & & $\begin{array}{l}2 \cdot 2 \\
2 \cdot 1\end{array}$ & $\begin{array}{l}0 \cdot 68 \\
0 \cdot 22\end{array}$ & $\begin{array}{l}3 \cdot 2 \\
3 \cdot 1\end{array}$ & $\begin{array}{l}0 \cdot 70 \\
0 \cdot 20\end{array}$ & $\begin{array}{l}0.97 \\
1 \cdot 10\end{array}$ \\
\hline $\begin{array}{l}\text { ic juice } \\
\text { lesium sulphate fraction } \\
\text { gnesium sulphate }\end{array}$ & Plasma protein & $\begin{array}{l}2 \cdot 3 \\
2 \cdot 2 \\
2 \cdot 3\end{array}$ & $\begin{array}{l}0 \cdot 77 \\
0 \cdot 71 \\
0 \cdot 25\end{array}$ & $\begin{array}{l}3 \cdot 4 \\
3 \cdot 2 \\
3 \cdot 4\end{array}$ & $\begin{array}{l}0 \cdot 84 \\
0 \cdot 65 \\
0 \cdot 22\end{array}$ & $\begin{array}{l}0.92 \\
1 \cdot 09 \\
1 \cdot 14\end{array}$ \\
\hline $\begin{array}{l}\text { cic juice } \\
\text { calcium phosphate gel } \\
\text { after adsorption on gel }\end{array}$ & Plasma protein & $\begin{array}{l}1 \cdot 9 \\
2 \cdot 0 \\
2 \cdot 0\end{array}$ & $\begin{array}{l}0 \cdot 63 \\
0 \cdot 12 \\
0 \cdot 49\end{array}$ & $\begin{array}{l}3 \cdot 4 \\
3 \cdot 3 \\
3 \cdot 2\end{array}$ & $\begin{array}{l}0.59 \\
0 \cdot 09 \\
0.50\end{array}$ & $\begin{array}{l}1 \cdot 07 \\
1 \cdot 33 \\
0.98\end{array}$ \\
\hline $\begin{array}{l}\text { ric juice } \\
\text { Amberlite IR-4 } \\
\text { after adsorption }\end{array}$ & Plasma protein & $\begin{array}{l}1 \cdot 8 \\
2 \cdot 1 \\
1 \cdot 8\end{array}$ & $\begin{array}{l}0.50 \\
0 \cdot 13 \\
0.48\end{array}$ & $\begin{array}{l}3 \cdot 5 \\
3 \cdot 5 \\
3 \cdot 3\end{array}$ & $\begin{array}{l}0.44 \\
0 \cdot 10 \\
0.42\end{array}$ & $\begin{array}{l}1 \cdot 14 \\
1 \cdot 30 \\
1 \cdot 14\end{array}$ \\
\hline
\end{tabular}

Hog-stomach extract

$0-50 \%$ ammonium sulphate fraction

$50-100 \%$ ammonium sulphate

fraction

Human gastric juice

$50-100 \% \mathrm{NaCl}$ fraction

Supernatant from $100 \% \mathrm{NaCl}$

fraction

Human gastric juice

$0-50 \%$ magnesium sulphate fraction

$50-100 \%$ magnesium sulphate

Human gastric juice

Eluate from calcium phosphate gel

Supernatant after adsorption on gel

Human gastric juice

Eluate from Amberlite IR-4

Supernatant after adsorption 
of the juice by dialysis against $50 \%(w / v)$ gum arabic. Dialysis at $0-5^{\circ}$ and at $\mathrm{pH} 2.5$ was continued until the juice was reduced to one-fiftieth of its original volume. The resulting supernatant liquid was very powerfully proteolytic and digested human-serum albumin with two maxima at $\mathrm{pH} 2 \cdot 0$ and $3 \cdot 6$. It no longer gave Molisch's test and did not reduce Benedict's solution upon hydrolysis. Its mucoprotein content was therefore thought to be minimal.

Two experiments were carried out in the Tiselius apparatus on different batches of gastric juice prepared in this way. Both showed at $\mathrm{pH} 2.5$ in $33 \mathrm{~mm}$-acetate- $\mathrm{HCl}$ buffer one major component moving slowly towards the anode and a smaller component also moving towards the anode. The $\mathrm{pH}$ of 2.5 was chosen in order that pepsin alone would be likely to migrate to the anode, whereas mucoprotein and any other proteolytic enzymes might move to the cathode. Samples of the two migrating components were obtained separately in the usual way and their proteolytic $\mathrm{pH}$-activity curves ascertained (Fig. 2).

Although both are apparently homogeneous electrophoretically at $\mathrm{pH} 2 \cdot 5$, they each exhibited two pH maxima. The maxima of the original juice and of the larger anodal component had similar $\mathrm{pH}$ values, but those of the smaller component were different, occurring at somewhat lower $\mathrm{pH}$ values. Pepsin is the only known component of gastric juice which is an anion at a $\mathrm{pH}$ as low as 2.5 . It seems likely therefore that both components were chiefly or wholly pepsins, rather than inert proteins with a small amount of adsorbed enzyme(s) attached as an impurity, and these experiments would suggest that, in its natural state, each pepsin component carries out its proteolytic activity with maxima at two different $\mathrm{pH}$ values. Again no evidence was obtained to support the existence of a separate 'cathepsin' in gastric juice.

Ultracentrifugal studies. It is known that in gastric mucous membrane, pepsin exists mainly as pepsinogen granules in the chief cells, and that when an aqueous extract is made, these granules or at least the pepsinogen from them, go into solution. The location of 'catheptic' activity is, however, unknown. Cathepsins are usually only to be found intracellularly, and if gastric 'cathepsin' were to be bound to cell particles other than the pepsinogen granules, differential ultracentrifuging of mucosal extracts might separate peptic and 'catheptic' activities. Accordingly, normal gastric mucosa was obtained within $2 \mathrm{hr}$. of death from a subject who had suffered fatal injury on the roads. An extract of it in $2 \%(\mathrm{w} / \mathrm{v}) \mathrm{NaCl}$, at $0^{\circ}$, was subjected, after removal of debris by centrifuging at $2000 \mathrm{rev} . / \mathrm{min}$. for $20 \mathrm{~min}$., to $38000 \mathrm{~g}$ for $30 \mathrm{~min}$. in the Spinco ultracentrifuge. Four layers were now obtained, a clear supernatant layer, a layer consisting mainly of microsomes, a layer mainly of mitochondria and a layer mainly of partly damaged cells. The components of each layer of the precipitate were identified microscopically but there was contamination of each layer and of the supernatant by particles of other layers engulfed in shreds of mucus.

The proteolytic activity of each of these layers is shown in Fig. 3. It will be observed that the original extract and the clear supernatant layer

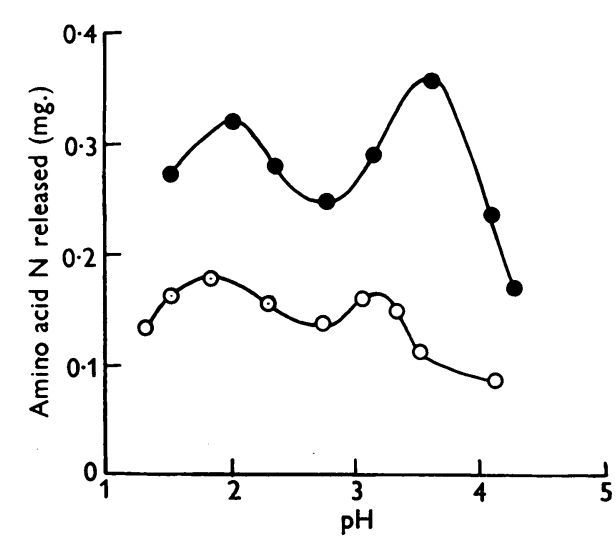

Fig. 2. pH-activity curves of two anodal-moving components separated from concentrated human gastric juice in the Tiselius apparatus. O, Major, faster component, mobility $2.99 \times 10^{-6} \mathrm{~cm} .^{2} / \mathrm{v} / \mathrm{sec}$; $O$, minor, slower component. Electrophoresis was carried out in 33 mm-acetate buffer, $\mathrm{pH} \mathbf{2 \cdot 5}$. Protein concentration, $0.51 \mathrm{~g} . / 100 \mathrm{ml}$. Human serum albumin as substrate; temp., $37^{\circ}$; time, $3 \mathrm{hr}$.

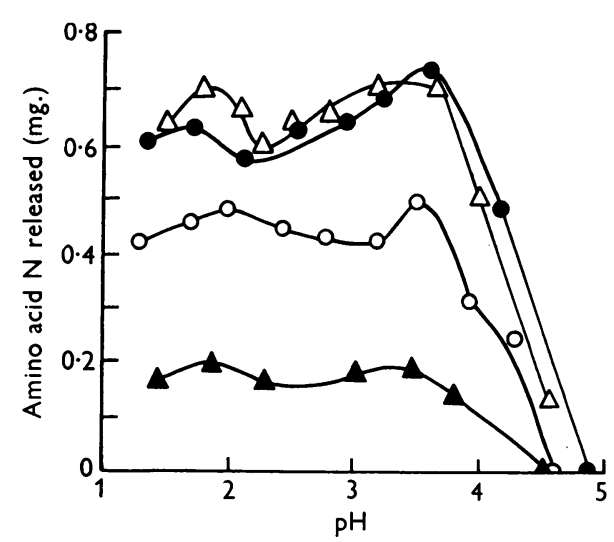

Fig. 3. $\mathrm{pH}-\mathrm{activity}$ curves of normal human gastricmucosal extract and of cell particles obtained from it by differential ultracentrifuging. O, Original extract; $\triangle$, supernatant layer from ultracentrifuge; $O$, microsomal layer; $\Delta$, mitochondrial layer. Human serum albumin as substrate; temp., $37^{\circ}$; time, $3 \mathrm{hr}$. 
each have two $\mathrm{pH}$ maxima and that the mitochondrial layer shows slight activity, without welldefined maxima, between $\mathrm{pH} 2$ and 4 . This probably results from contamination with the supernatant fluid. The microsomal layer could only be obtained mixed with supernatant fluid, from which it could not be distinguished proteolytically. These findings would indicate that proteolytic activity at pH 3-4 cannot be easily separated from that at $\mathrm{pH} 2$ by differential centrifuging and is therefore unlikely to be bound to cell particles.

\section{Attempts to vary activity independently at the two $\mathrm{pH}$ maxima}

If the activity at one $\mathrm{pH}$ maximum could be altered without altering that at the other, support would be given to those explanations of doublemaximal pH-activity curves which postulate a double enzyme-substrate interaction. Evidence from the preceding section has already indicated that small changes in the ratio of activity at the two maxima may be produced by treatment with salt solutions, but these changes are non-specific. If the maximum at $\mathrm{pH} \mathrm{3.3-4.0}$ is caused by 'catheptic' activity, activation by $\mathrm{H}_{2} \mathrm{~S}$, cysteine

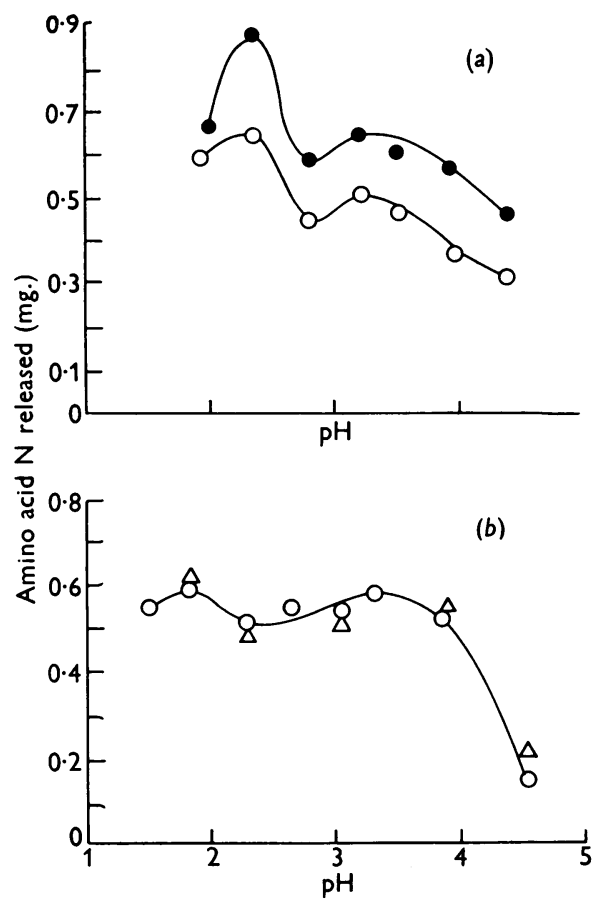

Fig. 4. (a) Effect on the pH-activity curve of saturating normal human gastric juice with $\mathrm{H}_{2} \mathrm{~S}$ : $\odot$, with $\mathrm{H}_{2} \mathrm{~S}$; $O$, without $\mathrm{H}_{2} \mathrm{~S}$. (b) Effect of 33 mM-cysteine upon the $\mathrm{pH}$-activity curve of normal human gastric juice: $O$, without cysteine; $\triangle$, with cysteine. Human serum albumin as substrate; temp., $37^{\circ}$; time, $3 \mathrm{hr}$. or the cyanide ion might be expected. Repeated observations with concentrations of these substances over a tenfold range have shown, however, that cysteine exerts no effect on either $\mathrm{pH}$ maximum (Fig. 4) but that $\mathrm{H}_{2} \mathrm{~S}$ and the cyanide ion mildly activate both maxima equally. The activity at both maxima is also rapidly destroyed by incubating at $37^{\circ}$ for short periods at $\mathrm{pH}$ values greater than 7. No differential effects on either maximum have thus been demonstrated.

\section{Chromatographic analysis of digestion mixtures}

If the optimum proteolytic activity of gastric juice at $\mathrm{pH} \mathrm{3 \cdot 3-4 \cdot 0}$ is in fact due to a second 'catheptic' enzyme it might be expected that the peptide or amino acid end-products of its action would differ from those obtained at $\mathrm{pH} 2.0$ by the action of pepsin. Accordingly, the digestion mixtures of gastric juice and plasma at $\mathrm{pH} 2.2$ and 4.0 (Table 2) were analysed chromatographically on paper. It is seen that there are several differences in the number, size and distribution of the spots. The constituents of individual spots have not been analysed but it is apparent that with both samples of gastric juice, digestion, as judged by the end products, runs a different course at the peptic and 'catheptic' $\mathrm{pH}$ maxima.

These observations confirm and extend those of Bramstedt \& Kröger (1954) and give support to those theories which postulate two distinct types of site for enzyme-substrate interaction.

\section{Preparation of a homogeneous gastric proteinase exhibiting two $\mathrm{pH}$ maxima}

The proteolytic $\mathrm{pH}$-activity curve exerted by a homogeneous gastric proteinase should provide important evidence about the nature of the two $\mathrm{pH}$ maxima. Attempts to prepare from human gastric juice or mucosal extracts a pepsin satisfying the necessary criteria of homogeneity were unsuccessful because of scarcity of material. The best achieved were the apparently homogeneous anodal-moving electrophoretic components described above. Crystalline swine pepsin is commercially available, however, and contains two principal components which account for about $96 \%$ of the whole (Herriott, Desreux \& Northrop, 1940; Hoch, 1950). It is a suitable material from which pepsin $A$ can be prepared (Herriott et al. 1940; Herriott, 1955).

Crystalline swine pepsin (Armour and Co., Ill., U.S.A.) was found to contain two electrophoretic components on paper at pH 3.5 in $0.2 \mathrm{M}$-acetate

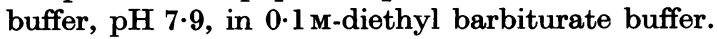
At both $\mathrm{pH}$ values both components move towards the anode, as would be expected of pepsin. The pH-activity curves which result from the action of this sample of crystalline pepsin upon plasma, bovine crystalline plasma albumin, bovine 
Table 2. Paper chromatography of products resulting from the action of two samples of normal human gastric juice on plasma protein at $\mathrm{pH} 2.2$ and 4.0 at $37^{\circ}$ for $2 \mathrm{hr}$.

Chromatogram in $78 \%(w / v)$ phenol-water, ninhydrin stain. The symbols + to ++++ are a semiquantitative indication of the size and density of the spots.

\begin{tabular}{|c|c|c|c|c|c|c|c|}
\hline \multicolumn{8}{|c|}{ lues } \\
\hline \multicolumn{4}{|c|}{$\mathrm{pH} 2 \cdot 2$} & \multicolumn{4}{|c|}{$\mathrm{pH} \mathrm{4.0}$} \\
\hline & $A$ & & $B$ & & $\boldsymbol{A}$ & & $B$ \\
\hline 0.05 & ++ & 0.05 & ++ & $\begin{array}{l}0.06 \\
0.08\end{array}$ & $\begin{array}{l}++ \\
+\end{array}$ & 0.06 & \\
\hline 015 & 1 & 0.11 & $1+$ & 0.12 & ++ & $0 \cdot 12$ & ++ \\
\hline 0.10 & ++ & 0.10 & ++ & $0 \cdot 19$ & + & $0 \cdot 19$ & + \\
\hline $0 \cdot 24$ & + & 0.24 & ++ & $\begin{array}{l}0.25 \\
0.33\end{array}$ & $\begin{array}{l}++ \\
+\end{array}$ & $\begin{array}{l}0.25 \\
0.34\end{array}$ & + \\
\hline 0.42 & + & & & 0.42 & + & 0.42 & + \\
\hline 0.52 & +++ & 0.52 & + & 0.54 & + & 0.55 & + \\
\hline 0.63 & ++ & $\begin{array}{l}0.62 \\
0.68\end{array}$ & + & & & $\begin{array}{l}0 \cdot 67 \\
0 \cdot 74\end{array}$ & + \\
\hline 0.79 & ++++ & 0.79 & ++++ & 0.78 & ++++ & 0.79 & ++ \\
\hline 0.92 & $+++t$ & 0.92 & ++ & 0.91 & +++ & 0.92 & + \\
\hline
\end{tabular}

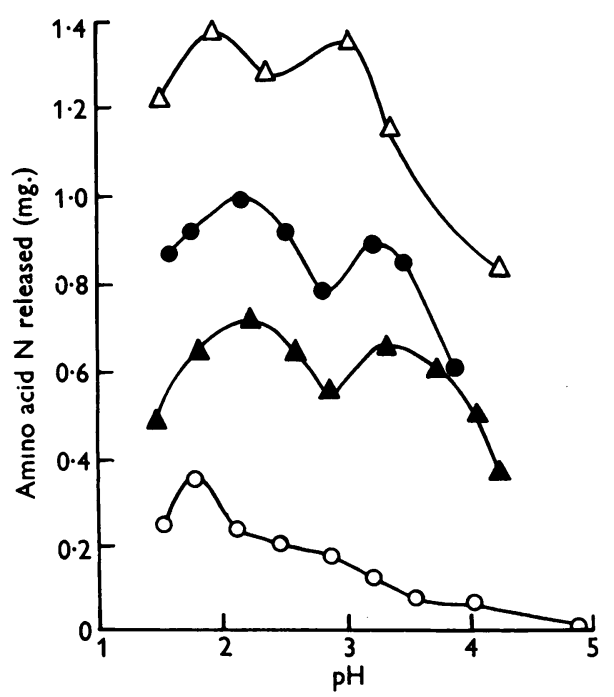

Fig. 5. pH-activity curves of crystalline swine pepsin (Armour and Co.) upon protein substrates. Temp., 37 ${ }^{\circ}$; time, $3 \mathrm{hr}$. $\triangle$, Crystalline bovine plasma albumin; , crystalline bovine plasma albumin fraction $\mathrm{V} ; \boldsymbol{\Delta}$, plasma protein; $\bigcirc$, egg albumin. Enzyme concentration $10 \mathrm{mg} . / 100 \mathrm{ml}$. of digest.

plasma albumin fraction $\mathrm{V}$ and egg albumin are shown in Fig. 5. Double maxima are found with each substrate other than egg albumin. These results resemble those reported for human gastric juice and swine gastric-mucosal extracts (Taylor, 1959). Pepsin A, prepared from crystalline pepsin, consisted of only one electrophoretic component at the same two $\mathrm{pH}$ values. When subjected to a constant-solubility test in 0.60 saturated magnesium sulphate solution and $20 \mathrm{~mm}$ acetate buffer, pH 4.8 (Taylor, 1959), only one component was present. This sample of pepsin $A$ digests itself, heat-denatured plasma albumin fraction $\mathrm{V}$ and heat-denatured crystalline plasma albumin with two maxima (Taylor, 1959).

In these instances it seems likely that a single enzyme component is attacking a single substrate component and in each instance the $\mathrm{pH}$-activity curve has two $\mathrm{pH}$ maxima. There is thus positive evidence that a double $\mathrm{pH}$ maximum may arise from a pure enzyme derived from swine gastricmucosal extracts. There is therefore no necessity to postulate the existence of a second 'catheptic' enzyme in the pig to account for the maximum at pH 3.3-4.0 which has been previously observed with swine gastric-mucosal extracts, and by analogy the existence of a human gastric 'cathepsin' would seem to be unnecessary, thus reinforcing the evidence leading to this conclusion which has already been derived from the electrophoretic experiments on human gastric juice.

\section{Enzyme and substrate titration curves}

If the two maxima result from the inactivity of the zwitterionic form of the enzyme and the activity of the anionic and cationic forms (hypothesis 6), or from the inability of the enzyme to form an active complex with the substrate zwitterion but only with the anionic and cationic forms of the substrate (hypothesis 7), it should be possible, by observing the titration curves of the enzyme, the substrates and mixtures of the two, to find out 


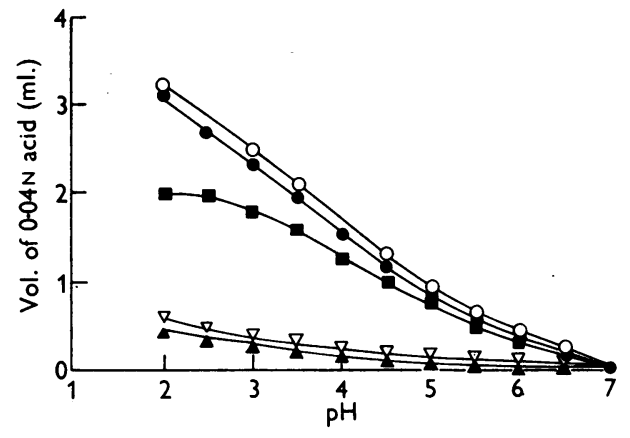

Fig. 6. Titration curves of: $\nabla$, bovine plasma albumin fraction $\mathrm{V} ; \Delta, \boldsymbol{\Delta}$, egg albumin; $\square$, pepsin $A$; and of immediately titrated mixtures of substrate with enzyme at room temperature. 0 , Egg albumin + pepsin A; $O$, fraction $V+$ pepsin $A$. For each the ordinate represents the volume of acid required to bring the system to the $\mathrm{pH}$ of the abscissa, in excess of that required to bring an equal volume of water to the same $\mathrm{pH}$. Initial concentration of substrates, $0.1 \mathrm{~g} . / 100 \mathrm{ml}$. Initial concentration of pepsin A, $0.2 \mathrm{~g} . / 100 \mathrm{ml}$. (approx.).

whether there is any coincidence of the $\mathrm{pH}$ maxima with the $\mathrm{pH}$ range over which the enzyme, the substrates or mixtures of both exist in anionic, cationic or zwitterionic forms. In Fig. 6 titration curves of pepsin A, substrates and immediately titrated mixtures of enzyme and substrate are shown. With pepsin $A$ it is seen that the steepest part of the titration curve occurs between $\mathrm{pH} \mathrm{3.5}$ and $4 \cdot 5$, that is to say, at the $\mathrm{pH}$ range over which proteolytic activity of the enzyme falls most markedly. Whatever the ionic form of the enzyme that is being produced, it is clearly an inactive form, in comparison with the form existing at pH 2.5. There are no inflexions in the titration curve in the range $\mathrm{pH} 2 \cdot 0-3 \cdot 5$, which might indicate that the two maxima found within this range could be caused by the activity of different ionic forms of enzyme. These results would in fact fit very simply into an explanation of a single $\mathrm{pH}$ maximum, as Michaelis found, but do not adequately explain a double maximum. The titration curves of substrates are similarly smooth and afford no evidence of changes of ionic form that could explain the existence of two $\mathrm{pH}$ maxima. The titration curves of mixtures of pepsin and substrate similarly provide no help. It may be pointed out that even though only one $\mathrm{pH}$ maximum is found with egg albumin, the titration curves are very similar to those of substrates which show two, again indicating that an explanation of the double $\mathrm{pH}$ maximum is not to be found from study of the ionic changes of enzyme and substrate with change of $\mathrm{pH}$. It should be noted too that if pepsin A were really a mixture of pepsin and cathepsin it might have yielded evidence in the titration curves of its heterogeneity. The lack of evidence of two components is in keeping with the view that only one enzyme component, capable of digesting proteins with two $\mathrm{pH}$ maxima, is present, although not, of course, affording definite proof of the absence of two.

\section{Effect of substrate concentration upon the $\mathrm{pH}$ maxima}

If the existence of two $\mathrm{pH}$ maxima were to depend upon the different effects of $\mathrm{pH}$ upon the initial combination of enzyme and substrate and upon its subsequent decomposition (hypothesis 8), the hypothesis could be tested by using the same methods as Gutfreund (1955) and Hammond \& Gutfreund (1955) used for trypsin and chymotrypsin. Unfortunately the first step in such an investigation would be the determination of the Michaelis constant $K_{m}$, for this, if the hypothesis be true, is the dissociation constant of the initial step. Several attempts have been made to measure a Michaelis constant for the reaction of pepsin with protein substrates, but in no instance has this been satisfactorily achieved. Such a result is not surprising when it is remembered that a protein substrate presents several different peptide bonds for hydrolysis and that these may perhaps be attacked at differing stages or in differing sequences. It was found that the initial velocity $(v)$ for digestion of protein substrates is not related to the substrate concentration $(s)$ in such a way that $1 / v$ plotted against $1 / s$ yields a straight line (Lineweaver \& Burk, 1934). It is thus not possible to pursue, after the manner of Gutfreund and Hammond, the hypothesis under investigation. Simple synthetic substrates cannot be used as they give only one $\mathrm{pH}$ maximum.

The problem can fortunately be attacked from another angle. If the initial reaction of enzyme and substrate has a dissociation constant which varies with $\mathrm{pH}$, the effect of $\mathrm{pH}$ can be minimized by carrying out the reaction at high substrate concentrations, so that the initial velocity $(v)$, whatever the $\mathrm{pH}$, approaches the maximal velocity $(V)$ and is therefore more or less the same at any individual $\mathrm{pH}$ value, provided that none of the enzyme or substrate has become inactivated by change of $\mathrm{pH}$. If the effect of $\mathrm{pH}$ upon the initial step can thus be eliminated or reduced, the effect upon the $\mathrm{pH}-$ activity curve would be to reduce or eliminate one of the maxima, if, as is supposed, one of them depends upon this reaction. Fig. 7 shows the effect of substrate concentration upon the two maxima which occur when gastric juice and crystalline bovine plasma albumin interact. It will be observed that although the maximum in the region of $\mathrm{pH} 2$ shifts to a slightly higher $\mathrm{pH}$ at the highest albumin concentration, the two maxima 
are still well delineated. It may be noted that the ratio of activity at the two maxima (pH $3 \cdot 2: \mathrm{pH} 2 \cdot 0$ ) falls as the substrate concentration rises. This indicates that activity at the maximum around $\mathrm{pH} 2 \cdot 0$ rises more rapidly with increasing substrate concentration than at the higher $\mathrm{pH}$ maximum, and implies that hydrolyses at the two maxima are chemically different processes. The curves do not, however, provide evidence to support the hypothesis that the two maxima are caused by differential effects of pH upon two different steps in an essentially single hydrolytic process.

\section{Digestion of partially digested protein substrates}

To investigate the hypothesis that the $\mathrm{pH}$ optimum of initial proteolysis might differ from the optimum for subsequent splitting of the products of initial proteolysis and in this way cause an overall pH-activity curve with two maxima, experiments have been carried out on the $\mathrm{pH}$-activity curves for digestion by gastric juice of previously partly digested substrates. Fig. 8 shows such a curve for the digestion of plasma which had been incubated with gastric juice for $1 \mathrm{hr}$. at $\mathrm{pH} 3.8$ and at $37^{\circ}$. It will be observed that digestion is relatively slight and that only a faint $\mathrm{pH}$ maximum is discernible in the region of $\mathrm{pH} \mathrm{2}$, but that there is an un-

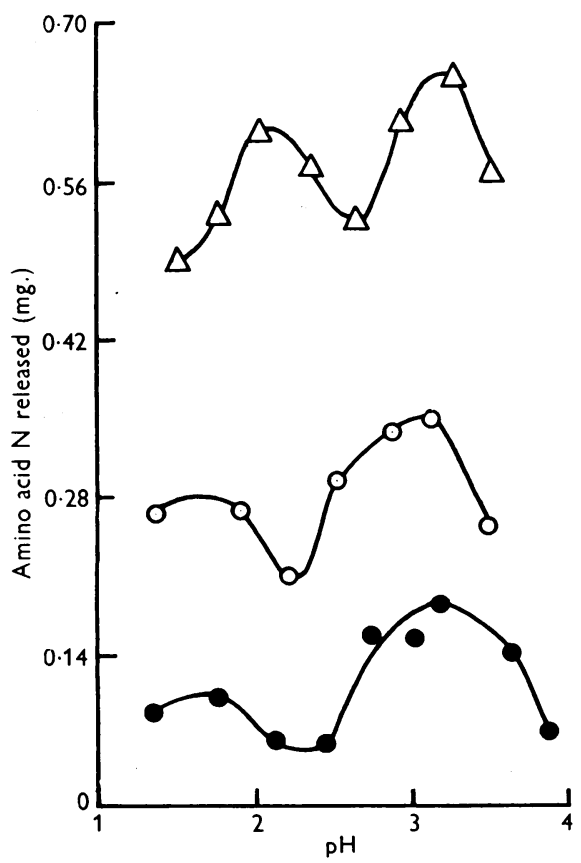

Fig. 7. Effect of substrate concentration upon the pHactivity curves of normal human gastric juice digesting crystalline bovine plasma albumin; temp., $37^{\circ}$; time, $3 \mathrm{hr}$. $0.2 \mathrm{~g} . / 100 \mathrm{ml}$. of digestion mixture; $0,0.4 \mathrm{~g} . /$ $100 \mathrm{ml}$; $\triangle, 1.6 \mathrm{~g} . / 100 \mathrm{ml}$. mistakable maximum at $\mathrm{pH} 3 \cdot 7$. This seems to indicate that digestion in the region of $\mathrm{pH} \mathrm{3.5}$ continues to occur optimally even after $1 \mathrm{hr}$., whereas digestion at $\mathrm{pH} 2$ is carried out without any optimum once it has been initiated at $\mathrm{pH} 3 \cdot 5$. The reverse experiment, digestion at varying $\mathrm{pH}$ values after preliminary digestion at $\mathrm{pH} \mathrm{2.3}$, yields a curve with three maxima. These experiments require further work for their proper interpretation, but they do not provide evidence that of the two pH maxima, one arises from a rapid proteinase action with only a little further splitting of the polypeptide products and the other from only a relatively slow proteinase action with rapid splitting of the polypeptides liberated.

If one of the maxima were caused by a rapid proteinase action it would be expected that this maximum alone would be present after short periods of digestion. It has been found, however, that two distinct maxima occur with digestion periods of as little as $10 \mathrm{~min}$. (Buchs, 1947), and that variation of the digestion time between $30 \mathrm{~min}$. and $6 \mathrm{hr}$. is without appreciable effect upon the position and relative magnitude of the two maxima (Taylor, 1959). There is thus further evidence that the hypothesis under investigation is unlikely to be correct.

\section{DISCUSSION}

It seems unlikely that the occurrence of two $\mathrm{pH}$ maxima in the proteolytic $\mathrm{pH}$-activity curves for gastric juice is caused by two separate enzymes, pepsin and 'cathepsin', for it has not been possible to separate the two substances nor to distinguish adequately between them from studies on activation and inhibition. On the other hand, evidence

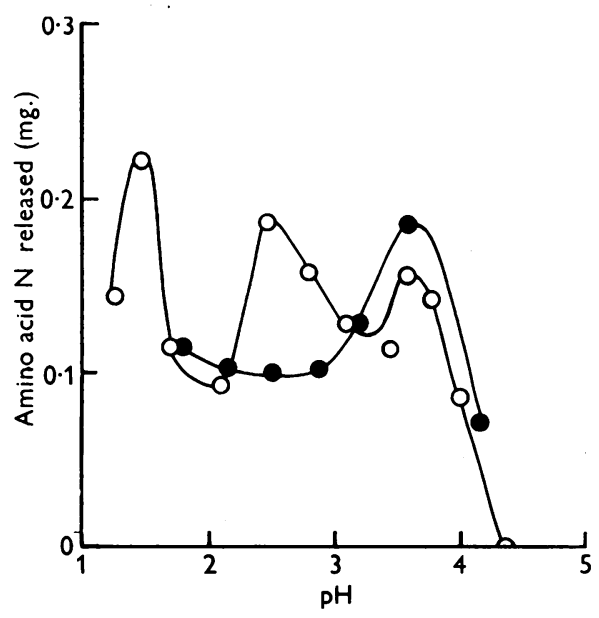

Fig. 8. pH-activity curves for digestion by normal human gastric juice of partly-digested plasma protein; temp., $37^{\circ}$; time, $3 \mathrm{hr}$. 0 , Previously incubated for $1 \mathrm{hr}$. at $\mathrm{pH} 3 \cdot 8$; O, previously incubated for $1 \mathrm{hr}$. at $\mathrm{pH} 2 \cdot 3$. 
has arisen, in attempting to separate the two postulated enzymes, that electrophoretically homogeneous components of gastric juice may produce pH-activity curves of proteolysis with two maxima, and that there are two such components. Attempts to confirm this evidence, using crystalline pepsin as starting material, have shown that the purest component of crystalline swine pepsin that could be prepared exhibited both $\mathrm{pH}$ maxima when acting upon a single substrate component. The conclusion that two $\mathrm{pH}$ maxima result from the action of a single enzyme component is thus supported by positive evidence as well as by the negative evidence of failure to isolate or separate components which are responsible for either one of the two $\mathrm{pH}$ maxima.

At least three other groups of workers (Buchs, 1947, 1954; Milhaud \& Lepine, 1949; Merten, Schramm, Grassmann \& Hannig, 1952) have attempted unsuccessfully to separate pepsin and 'cathepsin'. None has employed all the procedures that have been used here. Merten et al. (1952) concluded that of three components recognized on paper electrophoresis from a hydrochloric acid extract of swine mucous membrane, one contained the bulk of the pepsin activity but no 'catheptic' activity, the second gave maxima at $\mathrm{pH} 1.8$ and 3.5 (haemoglobin as substrate) and the third was inactive. Crystalline swine pepsin was investigated similarly and found to contain two components, one of which exhibited only peptic action and the other peptic and 'catheptic', thus resembling the first two components from the extract. Their results differ from those presented here in that a pepsin without a 'catheptic' action was obtained, but are similar in that 'catheptic' activity was not obtained alone. Buchs (1947) has tried to separate peptic and 'catheptic' actions by adsorption on charcoal, kaolin, fuller's earth, cholesterol, barium sulphate and ferric oxide at widely differing $\mathrm{pH}$ values, but the two activities always ran in parallel. He also prepared crystalline pepsin by Northrop's (1930) method, hoping thus to eliminate 'cathepsin', but peptic and 'catheptic' activities were both present in the crystals and markedly so, for 'cathepsin' after 'reactivation' by hydrogen sulphide or by potassium cyanide. Milhaud \& Lepine (1949) found that crystalline pepsin (The Armour Laboratories, and therefore presumably from swine) contained equal amounts of pepsin and 'cathepsin', but that ultracentrifuging did not permit separation of the two under the conditions employed. They concluded that the two ferments have similar molecular weights or that a single ferment has double activity. It is apparent that the results of many groups of workers lead to the conclusion that both $\mathrm{pH}$ maxima are the function of a single enzyme, and the positive proof attempted in the present investigation enhances this possibility.

Previous attempts to alter the activity at one or other $\mathrm{pH}$ maximum have given variable results. Buchs (1947) found that heating to $70^{\circ}$ and exposure to uranyl ions inhibited respectively the peaks at $\mathrm{pH} 2 \cdot 0$ and $3 \cdot 5$. These effects were, however, explained by Geilenkirchen \& Elbers (1950) and Crebolder, Engel \& Otten (1951) as resulting from the more rapid destruction of enzymic activity at $\mathrm{pH} 2.0$ with heating and at $\mathrm{pH} 3.5$ with precipitation by uranyl ions. Buchs also described activation at $\mathrm{pH} 3.5$ but not at $\mathrm{pH} 2.0$ by hydrogen sulphide, cysteine and potassium cyanide. Ramer (1954) confirmed this, using hydrogen sulphide and potassium cyanide. Geilenkirchen \& Elbers (1950) observed, however, that both $\mathrm{pH}$ maxima were equally activated by hydrogen sulphide, and this conclusion is supported by the results presented above. In contrast, Milhaud \& Epiney (1951), using edestin as substrate, and Merten et al. (1952), using haemoglobin, found that hydrogen sulphide and cysteine exerted no effect upon either enzymic action. The concensus of opinion, other than that of Buchs and Ramer, would thus incline towards the view that hydrogen sulphide, cysteine and potassium cyanide do not exert a specific effect upon the optimum at pH 3.5. Attempts to vary the activity at one or other maximum by the use of specific activators or inhibitors does not therefore seem to support those hypotheses (1 to 4) that postulate two enzymes or two types of active enzyme centre. On the other hand the different effects upon the two maxima that have been noted during attempted fractionation with salt solutions would best be explained if two enzymes or two types of enzyme centre were present.

The possible mechanisms by which a single enzyme could digest a single protein with two $\mathrm{pH}$ maxima have not been considered by previous workers. The experimental evidence presented above lends no support to those mechanisms which are modifications of the current hypotheses of the origin of $\mathrm{pH}$-activity curves with single maxima. Also, in that these modifications imply a single site for enzyme-substrate interaction, they are negatived by the evidence that different proteolytic products are formed at the two maxima and that increasing substrate concentrations affect the rate of proteolysis at the two $\mathrm{pH}$ maxima differently. It has also been shown that different $\mathrm{pH}$ optima for digestion of proteins and of proteolytic products do not account for the two maxima, even though it is established that synthetic peptides are split by gastric juice in the range $\mathrm{pH} \mathrm{3.5-4 \cdot 0}$ (Taylor, 1959).

That an inhibitor acting between $\mathrm{pH} 2.5$ and 3.2 might cause a pH-activity curve with two maxima 
is also unlikely, for it would mean that the true $\mathrm{pH}$ optimum of 'uninhibited' pepsin is around $2 \cdot 9$, whereas values much nearer $\mathrm{pH} 2$ have usually been found experimentally in $\mathrm{pH}$-activity curves with only one optimum. In the experiments with pepsin A described above, it is unlikely that an inhibitor, whether protein or non-protein, could be present, for a protein inhibitor would be detected as an impurity in the electrophoretic and solubility tests, and a smaller molecule would have been lost during the dialysis to which pepsin A was several times subjected during its preparation. In gastric juice or mucosal extracts two possible inhibitors might be present, pepsin inhibitor and mucoprotein. The former is, however, inactivated rapidly in the presence of pepsin with a $\mathrm{pH}$ maximum near 3.5 (Northrop et al. 1948). Since all samples of gastric juice used in this investigation have been secreted at $\mathrm{pH} 2.5$ or less and stored at between $\mathrm{pH} 3$ and 4, it is unlikely that pepsin inhibitor could have been responsible for the presence of two $\mathrm{pH}$ maxima of proteolysis. After removal of at least the major part of the mucoprotein, as in the electrophoretic experiments, two $\mathrm{pH}$ maxima are still found. This is in agreement with the observation of Heatley (1956) that the peptic activity of swine pyloric juice is uninfluenced by the addition of mucoprotein previously separated from it. The above evidence, taken together, would seem to indicate that two maxima may exist in the absence of substances that may possibly inhibit gastric proteolysis.

After excluding the possibilities that two enzymes are present and that interaction of enzyme and substrate occurs at only one site, there remain three mechanisms for consideration, each involving a double enzyme-substrate union. Of these, the first, that an enzyme with two active centres may attack the same type of substrate site with each centre, fails to account for several observed facts: it does not explain why different hydrolytic products are formed at the two pH maxima, nor why egg albumin should show only one $\mathrm{pH}$ maximum with the same sample of gastric juice or pepsin that gives two when acting on other substrates, nor why only one $\mathrm{pH}$ maximum should be shown with many synthetic substrates, nor why a wider variety of the peptide bonds of insulin should be split (Sanger \& Thompson, 1953) than would be expected from a knowledge of the action of pepsin on synthetic substrates.

The second possible mechanism is the reverse of the first, namely that a single enzyme centre should attack two sorts of substrate site with different $\mathrm{pH}$ maxima. This hypothesis would account for occurrence of different digestion products at the two $\mathrm{pH}$ maxima, and for the existence of substrates with only one $\mathrm{pH}$ maximum, by supposing that in such substrates only one substrate site is repre- sented. The hypothesis does not, however, provide a very adequate explanation of the present obser. vations that gastric juice can be altered by salt solutions in such a way that the ratio of activity at the two maxima is changed, nor of those of Norris \& Elam (1940) that the pepsin molecule can be so altered by different methods of preparation that only one of the two maxima occurs.

To account adequately for all the observations presented in this paper and for the results of previous workers, it is necessary to adopt the third explanation that two active enzyme centres each attack two different types of substrate bond maximally at different $\mathrm{pH}$ values. The production of curves with single maxima as a result of modifying the enzyme may then be explained as an inactivation of one of the enzyme centres. The results of Baker (1951) on the hydrolysis by pepsin of synthetic peptides lend additional support to this explanation. She divides the synthetic substrates of pepsin into two groups, 'those in which a phenylalanine or tyrosine residue is linked to certain non-aromatic amino acids and those in which two aromatic amino acid residues are linked to each other'. The first are hydrolysed slowly by pepsin with a $\mathrm{pH}$ optimum around 4, whereas those in the second group are hydrolysed rapidly with a $\mathrm{pH}$ optimum between 1.8 and 2.0 . There is thus independent evidence of the existence of two types of substrate site which may each be attacked at the two different $\mathrm{pH}$ values at which proteins are maximally digested.

The evidence which is at present available thus favours the hypothesis that pepsin has two active enzyme centres which attack substrates at two particular groups of peptide bonds, and that a separate gastric cathepsin does not exist. Final proof of the existence of two enzyme sites can, however, only be obtained either by a complete knowledge of the structure of pepsin and identification of the sites, or by the fragmentation of the pepsin molecule into units that possess only one of the active sites. In other words, pepsin and 'cathepsin' have still to be separated, but now from fragments of a single molecule.

\section{SUMMARY}

1. Fractionation of human gastric juice and swine gastric-mucosal extracts with ammonium sulphate, sodium chloride and magnesium sulphate has failed to achieve separation of enzymes responsible for the two proteolytic $\mathrm{pH}$ maxima which

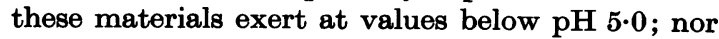
could separation be achieved by adsorption on calcium phosphate gel, on ion-exchange resins, by electrophoresis in the Tiselius apparatus and by differential ultracentrifuging. 
2. During electrophoresis of gastric juice, two anodal-moving homogeneous components at $\mathrm{pH} 2.5$ were isolated. Each digested proteins with two pH maxima below $\mathrm{pH} \mathrm{5.0.} \mathrm{The} \mathrm{maxima} \mathrm{of} \mathrm{the} \mathrm{smaller}$ component occurred at lower $\mathrm{pH}$ values than the corresponding maxima of the larger.

3. Hydrogen sulphide caused an increased liberation of amino groups by gastric juice from human serum albumin at all values between $\mathrm{pH} \mathbf{1 . 5}$ and 5.0. Cysteine was without effect on proteolysis over this range.

4. The ratio of activity at the two $\mathrm{pH}$ maxima was changed during treatment of gastric juice with salt solutions, indicating that one maximum could be altered independently of the other.

5. Paper-chromatographic analysis revealed that the end products of digestion at the two maximal $\mathrm{pH}$ values are different.

6. Crystalline swine pepsin, like human gastric juice, digests plasma protein, bovine crystalline plasma albumin and bovine plasma albumin fraction $\mathrm{V}$, with two $\mathrm{pH}$ maxima below $\mathrm{pH} 5 \cdot 0$, but egg albumin with only one. Pepsin A was isolated from crystalline pepsin, was found to be homogeneous by paper-electrophoretic and solubility tests, and to digest single component substrates with two maxima.

7. Attempts to explain the existence of two $\mathrm{pH}$ maxima in terms of enzyme-substrate union at a single site were unsuccessful.

8. It is suggested that the two proteolytic $\mathrm{pH}$ maxima which may be exhibited by gastric juice and gastric mucosal extracts below $\mathrm{pH} 5.0$ result from the action of a single enzyme, pepsin, which achieves this effect because it possesses two sorts of active centre, each of which attacks maximally at a different $\mathrm{pH}$ a different type of substrate site.

I wish to thank Miss Barbara Hunt for skilled assistance during part of this work; many colleagues, students and patients for supplying gastric juice; Dr A. G. Ogston, F.R.S., for facilities for differential ultracentrifuging; Dr E. O. Field for supervising the use of the Tiselius electrophoretic apparatus; and Dr R. B. Fisher and Mr J. R. P. O'Brien, with whom many aspects of this work have been discussed and who have read and eriticized the D.M. thesis from which the material of this paper is abridged.

\section{REFERENCES}

Baker, L. E. (1951). J. biol. Chem. 193, 809.

Bramstedt, F. \& Kröger, G. (1954). Die Med. 36, 1.

Buchs, S. (1947). Biologie des Magenkathepsins. Basel: Karger.

Buchs, S. (1954). Enzymologia, 16, 193.

Crebolder, A. J. M., Engel, C. \& Otten, C. J. (1951). Enzymologia, 15, 103.

Freudenberg, E. (1940). Enzymologia. 8, 385.

Geilenkirchen, W. L. M. \& Elbers, P. F. (1950). Enzymologia, 14, 304.

Gutfreund, H. (1955). Trans. Faraday Soc. 51, 441.

Hammond, B. R. \& Gutfreund, H. (1955). Biochem. J. 61, 187.

Heatley, N. G. (1956). Quart. J. exp. Physiol. 41, 25.

Herriott, R. M. (1955). In Methods in Enzymology, vol. 2. Ed. by Colowick, S. P. \& Kaplan, N. New York: Academic Press Inc.

Herriott, R. M., Desreux, V. \& Northrop, J. H. (1940). J. gen. Physiol. 24, 213.

Hoch, H. (1950). Nature, Lond., 165, 278.

Kunitz, H.\& Northrop, J.H.(1934). J.gen. Physiol. 17, 591.

Lineweaver, H. \& Burk, D. (1934). J. Amer. chem. Soc. 56, 658.

Merten, R. \& Ratzer, H. (1949). Klin. Wschr. p. 587.

Merten, R., Schramm, G., Grassmann, W. \& Hannig, K. (1952). Hoppe-Seyl. Z. 289, 173.

Michaelis, L. (1914). Die Wasserstoffionen-Konzentration. Berlin: Springer. Quoted in Northrop, Kunitz \& Herriott (1948).

Milhaud, G. \& Epiney, J. (1951). Gastroenterologia, Basel, 77, 193.

Milhaud, G. \& Lepine, P.(1949). Ann. Inst. Pasteur, 77, 335.

Norris, E. \& Elam, E. (1940). J. biol. Chem. 134, 443.

Northrop, J. H. (1922). J. gen. Physiol. 5, 263.

Northrop, J. H. (1925). J. gen. Physiol. 8, 261.

Northrop, J. H. (1930). J. gen. Physiol. 13, 739.

Northrop, J. H., Kunitz, M. \& Herriott, R. M. (1948). Crystalline Enzymes, 2nd ed. New York: Columbia University.

Ramer, Z. (1954). Hoppe-Seyl. Z. 296, 73.

Ringer, W. E. (1915). Hoppe-Seyl. Z. 95, 195.

Sanger, F. \& Thompson, E. O. P. (1953). Biochem. J. 53, 366.

Smith, E. L., Finkle, B. J. \& Stockell, A. (1955). Disc. Faraday Soc. 20, 96.

Taylor, W. H. (1956). D.M. Thesis: University of Oxford. Taylor, W. H. (1957). Analyst, 82, 488.

Taylor, W. H. (1959). Biochem. J. 71, 73.

Tiselius, A., Henschen, G. E. \& Svensson, H. (1938). Biochem. J. 32, 1814.

Wilkinson, J. \& Martin, G.J. (1946). Arch. Biochem. 10, 205. 